\title{
Mechanisms of DNA repair in mitochondria
}

\author{
A. S. Singatulina, P. E. Pestryakov \\ Novosibirsk Institute of Chemical Biology and Fundamental Medicine, Siberian Branch of the Russian Academy of Sciences \\ 8, Akademika Lavrentieva Ave., Novosibirsk, Russian Federation, 630090
}

\begin{abstract}
The role of mitochondria in cellular metabolism and functioning can hardly be overestimated. Mitochondria carry out many functions, and their main function is the production of ATP, the energetic "currency" of the cell. Mitochondria possess a small circular DNA, which codes for 13 proteins. Mitochondrial DNA, or mtDNA, as well as the nuclear one, is subjected to the influence of environmental and endogenous factors. This may lead to mtDNA damage. Here we review the data on mtDNA damage and repair mechanisms. The functioning of mitochondria directly depends on integrity of mtDNA, and therefore, on correct functioning of the mtDNA repair system. These systems differ from the repair systems of nuclear DNA and are in general understudied. The existence of excision nucleotides repair system correcting bulky lesions in mitochondria is still under question. Specific degradation of damaged mtDNA can probably serve as an alternative way to prevent the accumulation of bulky lesions. A search for new pathways of mtDNA repair is of considerable interest.
\end{abstract}

Ke y w o r d s: Mitochondrial DNA, mtDNA repair system, mtDNA damages.

The presence of mitochondria, which evolved from the purple bacteria, is with rare exceptions a typical feature of the eukaryotic cells [1]. Mitochondria carry out various functions. The main of them is, undoubtedly, energetic metabolism. Besides, mitochondria take part in the regulation of $\mathrm{Ca} 2+$ ion concentrations, heme, biosynthesis, development of cellular response to physical and chemical agents, apoptosis and necrosis, immune response, generation of active forms of oxygen (AFO), as well as in growth and differentiation of the cell [2-6]. Mitochondria also play an important role in ageing process. Additionally, numerous diseases are associated with mitochondrial dysfunction.

The results of several studies testify that a wide spectrum of damages similar to the damages in nuclear DNA can appear in mitochondrial DNA. Close proximity of mitochondrial DNA to the complexes of electron transport chain can lead to the increased effects of reactive oxygen forms and other radicals on mitochondrial DNA. mtDNA is possibly more prone to damage because of a high level of metabolism in mitochondria in comparison with the nucleus. Thus, the problem of $\mathrm{mtDNA}$ repair is crucial for the maintenance of normal vital activity in the cell. It was believed earlier that there were no DNA repair systems in mitochondria, damaged molecules are degrading, replication and transcription of mtDNA are running with undamaged molecules, what is due to multiple copies mtDNA.

The first mechanism of repair, which was found in mitochondria, is a system of bases excision repair, BER, particularly its short-patch repair system, SPBER, which is in general similar to the nuclear SPBER [7]. Long-patch way, LP-BER, was discovered later [7]. The BER system is the most well studied system of mitochondrial DNA repair, but only limited range of damages is processed via this way: damages of bases, which result from reactions of oxidation, deamination, alkylation and spontaneous

(C) 2016 A. S. Singatulina et al.; Published by the Institute of Molecular Biology and Genetics, NAS of Ukraine on behalf of Biopolymers and Cell.

This is an Open Access article distributed under the terms of the Creative Commons Attribution License (http://creativecommons.org/licenses/by/4.0/),

which permits unrestricted reuse, distribution, and reproduction in any medium, provided the original work is properly cited 
hydrolysis. Later the system of mismatched bases repair, MMR, was discovered, which has mechanisms of functioning different from those in the nuclear MMR system $[8,9]$. There are data on the presence of single-strand break repair system, SSBR, homologous and non-homologous double-strand breaks recombination, elimination of premutagenic deoxynucleotides from the pool of deoxynucleotides, degradation of damaged mtDNA, but mechanisms of functioning of these systems are yet unknown or poorly studied $[10,11,12]$. Thereby the questions arise about the destiny of mtDNA containing clustered damages (multiple damages within the limits of 1-2 turns of DNA helix). Besides, there are no evidences of the presence of nucleotide excision repair, NER, in mitochondria, therefore a question about repair of bulky lesions in mtDNA appears. Researches are showing that clustered and bulky lesions in mtDNA do not accumulate, and repair of such damages in mitochondria is probably going in other way than in nucleus.

\section{Mitochondrial genome}

It is still amazing that after 1.5 billion years of symbiosis under conditions of natural selection mitochondria retain the rudimental genome represented by a circular DNA molecule; the./ size of human mtDNA is 16,568 thousands of nucleotide pairs [13, 14]. Whereas the mitochondrial proteome consists of 8001200 proteins, mtDNA codes only 13 proteins, which participate in ATP synthesis, 22 tRNAs and 2 rRNAs $[13,15]$. A feature of mitochondrial genome is high density of genes - in the sequence of mtDNA about 600 non-coding nucleotides are distinguished, most of which are part of a D-loop containing the regulatory elements of repair $[16,17]$. mtDNA transcription is polycistronic and passes from one promoter from heavy $(\mathrm{H})$ or light $(\mathrm{L})$ chain. Fig.1 represents the map of human mitochondrial DNA.

mtDNA is stored in matrix of mitochondria in complex with TFAM protein (mitochondrial transcriptional factor A) [18]. Such protein-nucleic complex is called nucleotide. TFAM carries out several important functions: it packs DNA in conformation typical for nucleotide, participates in DNA transcription, limits an access to mtDNA for genotoxic compounds $[19,20]$. At certain moments other proteins can enter into composition of nucleotide. During replication and transcription these "other" proteins are: mitochondrial analog of SSB which connects single-stranded DNA, mtSSB, mitochondrial RNApolymerase, DNA-polymerase $\gamma$, pol $\gamma$, helicases Twinkle and SUV3, transcriptional factor TFB2M [21]. It was believed for a long time that pol $\gamma$ is the only DNA-polymerase in mitochondria, but recent studies showed the localization of REV3 in mitochondria from different types of mammalian tissues and cell lines $[22,23]$. REV3 interacts with pol $\gamma$ and protects mtDNA from damage [23]. The studies show that one nucleotide contains one mtDNA molecule, but there is more than one nucleotide in each mitochondria. Mitochondria are dynamic structures and are able to "merge" and "divide" with exchanging contents of mitochondria, including nucleotides and RNA-transcripts $[20,21]$. The exchange of contents significantly influences functioning of mitochondria in the cell, because the exchange of damaged and active components of mitochondria takes place. At the same time there is still no clear confirmation of enhancement of mitochondrial functioning due to increasing the intensity of merging-dividing process [24].

Because of proximity to the electron transfer chain and high density of electrons, the damages of mtDNA are able to influence the process of expression, firstly, due to arising nucleotide modifications, secondly, due to blocking the transcriptional machine with use of damaged DNA matrix. The mechanisms contributing to the preservation of mtDNA integrity and thus normal mitochondrial functioning will be reviewed further in detail.

\section{Damages of mitochondrial DNA}

Polymorphism of mitochondrial DNA genes and somatic mutations were studied with goal to understand the causes of hereditary diseases and their connection to life expectancy. According to the recent information placed in database MITOMAP - Human mito- 
chondrial genome database, about 200 pathogenic mutations, deletions or insertions which are inherited, exist in mtDNA [25]. Certain sequences of mtDNA, such as hypervariable sites of D-loop, can be connected with the state of health in advanced age [26]. Currently quite a large amount of oligonucleotide polymorphisms in mitochondria is known, but only several of them cause diseases [27-29]. It is also necessary to note that cells can contain thousands of copies of mtDNA, thus, reaching a certain threshold level of mtDNA damage is necessary for appearance of symptoms of mitochondrial dysfunction.

Mitochondrial DNA, as well as nuclear one, is exposed to harmful agents from the environment, such as industrial waste, medicines, radiation exposure. Additionally, chemical radicals formed during cell metabolism also possess a damaging effect. Unlike nuclear DNA, mtDNA is more complicated object for studying the structure and number of damages, because it is only a small part of total cellular DNA. In last years numerous studies on measurement of damage in mtDNA were carried out and accented on specific damages, which play important role in mtDNA mutagenesis or diseases associated to dysfunction of mitochondria. Some types of mtDNA damages found in human cells and probably influencing expression of mtDNA genes are described below.

\section{Damages caused by endogenous processes}

Correct functioning of mitochondria has paramount importance for cell, because mitochondria are the main source of energy. In the process of oxidative phosphorylation mitochondria consume up to $90 \%$ of oxygen which entered the cell. During ATP synthesis via electron transport chain (ETC) there is a "leakage" of electrons, which interact with oxygen

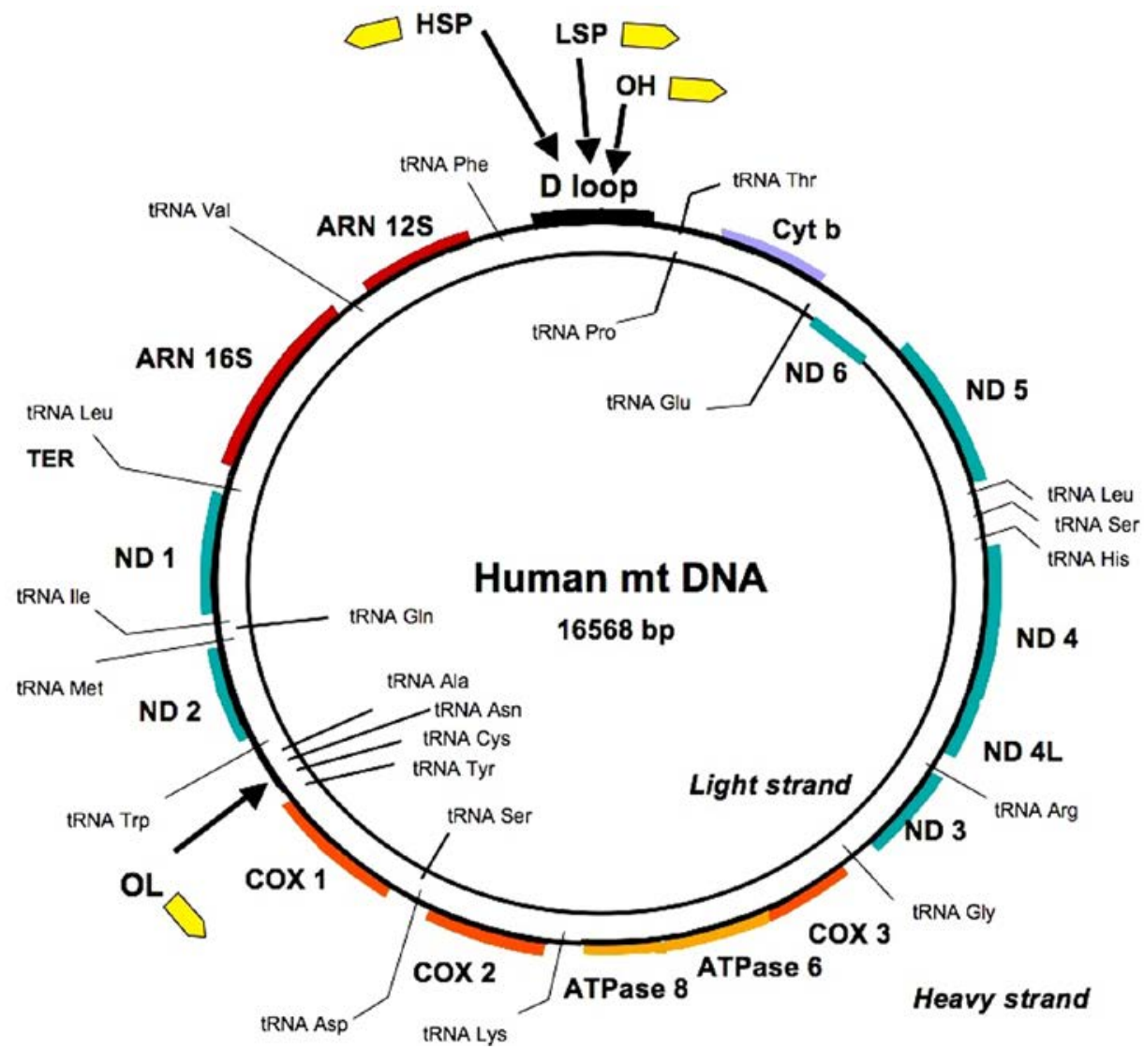

Fig. 1. Map of human mitochondrial DNA [13]. mtDNA codes 13 proteins: ND1-6, subunits of NADH-dehydrogenase; COX1-3, subunits of cytochrome c-oxidase; ATP6 and ATP8; subunits of ATPsynthetase; cytochrome b; 22 tRNA; 2 rRNA - ARN 16S and ARN 12S. D-loop contains promoters of heavy and light replication chains as well as originals of replication of heavy (OH) and light (OL) chains. 
molecule and form a superoxide anion $\mathrm{O}_{2}^{-}$(up to $2 \%$ of oxygen, which entered the cell, participate in this process) [30-33]. A superoxide anion then is transformed to hydrogen peroxide by superoxide dismutase Mn-SOD, hydrogen peroxide is metabolized into molecules of water and oxygen by glutathione peroxidase or can diffuse into other organoids of the cell [34]. In cytoplasm, hydrogen peroxide is metabolized by catalase and other enzymes. Except $\mathrm{O}_{2}{ }^{-}$, during reaction in ETC other intermediates of the reaction can "leak" - e.g., AFO or hydroxyl radicals. Besides, radicals and other damaging agents can also result from metabolic reactions, which are not related to the process of oxidative phosphorylation.

AFO and especially a superoxide anion, the most chemically active radical, can lead to the damages in DNA, proteins and lipids not only in mitochondria, but also in other organoids of the cell [35]. For example, lipid peroxidation is a radical chain reaction of lipid oxidation launched by hydroxyl radical. This reaction results in the formation of electrophilic aldehydes, which react with residues of cysteine, lysine, arginine and histidine in proteins and with animo groups of DNA bases [7, 36]. The widespread compounds forming adducts with DNA are formaldehyde, malonic dialdehyde, cardiolipin, acrolein etc. Aldehyde products can undergo further changes depending on their initial structure. For example, formaldehyde initiates the formation of covalent crosslinks between proteins and DNA as well as the formation of $\mathrm{N}^{2}$-hydroxymethyl adducts of guanine. Electrophilic aldehydes are metabolized in mitochondria by aldehyde dehydrogenase or take part in reaction of conjugation with glutathione.

AFO are not only damaging agents, but also intermediates of numerous processes, including the cell adhesion, apoptosis, autophagy, immune response and cell differentiation, therefore control of the AFO level is absolutely necessary [38-43].

In cells, there are also chemically active forms of nitrogen [36, 37]. These substances are formed at the interaction between superoxide anion and nitrogen oxide. For example, peroxynitrite can oxidize heterocyclic bases of DNA, especially guanine, form- ing 8-nitro guanine. Peroxynitrite is also able to interact with sugar-phosphate backbone of DNA, which leads to gaps in the DNA chain. Another widespread chemically active form is nitrogen anhydride, which can cause deamination of bases at the interaction with DNA.

Oxidative damages of $\mathrm{mtDNA}$ are of special interest for researchers, because mtDNA in nucleotide is associated with the inner membrane of mitochondria containing numerous proteins in its structure, including proteins of ETC, functioning of which leads to the AFO formation. Oxidative damages are most common and diversified among all mtDNA damages; about 100 types of oxidative damages of mtDNA were registered in vivo. Apart from interaction with nucleic acids, oxidants can react with pool of free nucleotides, which are used in the synthesis of mitochondrial DNA and RNA. The results of studies carried out until recently testified in favor of more content of oxidative damage in mtDNA as compared with nuclear DNA. However, nowadays the data obtained via more precise and contemporary methods show that the level of damage in mtDNA is comparable with that in nuclear DNA.

One more common type of DNA damages is AP sites, which appear in cell mainly due to loss of purine bases. They are formed permanently in amount of about 50.000 a day per mammalian cell [44]. Deoxyribose of AP site can oxidized with opening of circular shape and formation of chain gap.

In the life processes of mitochondria, the interstrand DNA crosslinks can be formed under topoisomerase action. Characterization of mitochondrial topoisomerases of $1^{\text {st }}$ type, Top1mt and Top3 $\lambda \mathrm{mt}$ with further detection of cutting sites in the D-loop allowed supposition that the cause of deletions and degradation of mtDNA can be activity of mutant topoisomerase [45].

\section{Damages caused by exogenous factors}

Chemical substances arriving from the environment, metabolites of components of nutritive compounds, drugs, solar radiation are the sources of DNA damage. The components of cigarette smoke, benzo[a] 
pyrene and acrolein, aflatoxin B1, chemotherapeutic drugs containing platinum, and UV-radiation cause mtDNA damages, which inhibit transcription and replication [46, 47].

UV-radiation leads to the formation of covalent crosslinks between neighbouring pyrimidine bases, which results in forming the intrachain cyclobutane dimers or pyrimidine-(4,6)-pyrimidine photoproducts. One of the common damages appearing under action of UV-radiation or ionizing radiation is 5-formyluracyl, 5-FoU [48]. Formyl group 5-FoU can react with surroundings, e.g. with DNA-binding proteins and form covalent adducts [49]. UV-radiation also can be a reason of a higher level of AFO [50] causing oxidative DNA damages.

Exogenous sources also include aldehydes, production of which in tissues of organism increases during metabolism of alcohol under physiological conditions [51, 52]. Acetaldehyde is formed in large quantity in liver and is metabolized in mitochondria to acetate by aldehyde dehydrogenase $2, \mathrm{ALDH} 2$. If $\mathrm{ALDH} 2$ is unable to provide sufficient metabolism of acetaldehyde, the latter forms a number of adducts with DNA, which are able to interact with next acetaldehyde molecule and form interstrand crosslinks in DNA [53, 54]. Industrial waste contains formaldehyde combined with alkylating agents; it leads to formation of $\mathrm{N}^{2}$-hydroxymethyl-adducts of guanine and its derivatives under further influence of methylating agents.

Cigarette smoke contains acrolein, crotonaldehyde, formaldehyde and polycyclic aromatic hydrocarbons, such as benzo[a]pyrene and some typical for tobacco smoke N-nitrosamines, the interaction of which with DNA leads to formation of bulky adducts and interstrand crosslinks. Carcinogenic and toxic effect of environmental factors can be conditioned by the mtDNA damage caused by xenobiotics derivatives, such as in the case of benzo[a]pyrene, aflatoxine B1, as well as AFO formed in the process of activation of xenobiotics by cytochromes. For example, benzo[a]pyrene is metabolized in liver by cytochrome P450 CYP1A1 to benzo[a]pyrene-7,8dihydrodiol-9,10-epoxide. It was shown that both these compounds accumulate in mitochondria and inhibit synthesis of mtDNA $[55,56]$. The studies revealed that in metabolism of widespread polychlorinated biphenyls by liver cytochromes, the level of AFO increases [57]. A higher level of adducts of xenobiotics and DNA was found in liver cells of mice, which underwent an influence of polychlorinated compounds.

The studies show that dioxins from herbicides disrupt the membrane potential of mitochondria and raise the AFO level, what induces oxidative damages in mtDNA [58]. A lot of antitumor drugs damage DNA directly or indirectly, decreasing tumor growth and inducing apoptosis. Bleomycin and neocarzinostatin cause DNA damage by increasing the AFO and electrophilic aldehydes levels [59]. Anticancer therapeutics containing platinum compounds, such as cisplatin, carboplatin and oxaliplatin, bind to DNA with formation of adducts with one of several nucleotides, what leads to formation of inter- and intrastrand crosslinks through guanine. Even small number of interstrand crosslinks is disastrous for the replication process, because crosslinks lock divergence of DNA strands, which is necessary for the functioning of DNA polymerases $[60,61]$.

\section{Clustered damages}

Nowadays it is obvious that not only type, but also location of DNA damage is of significant importance for effective repair. The situation, when several damages are located within limits of 1-2 turns of the DNA helix and form so-called clustered damages, is of interest [62-64]. The clustered damage can have different types of damages in its structure: DNA chain gap, damaged bases, damaged sugar-phosphate backbone, and AP sites. Fig. 2 presents the scheme of possible clustered damages. Clustered damages in structure have to be repaired consistently and in particular sequence, otherwise double-strand DNA breaks, ds-breaks, can emerged, which are the biggest threat for the cell [65-69].

The examples above testify to an extremely wide spectrum of substances and processes causing various damages in cell DNA, including mtDNA. For 
restoring the integrity of mtDNA there are a number of mechanisms and systems which will be overviewed below.

\section{Repair of mitochondrial DNA in mammalians}

As it was said, the damages requiring repair emerge in mtDNA just like in nuclear DNA. For a long time the existence of effective mtDNA repair mechanisms was doubted. It was presumed that damaged mtDNA degrade, and transcription and replication of mtDNA run from undamaged mtDNA, the presence of which is provided by multiple copies of mtDNA in mitochondria. This suggestion was based on the experiments, which showed that the model DNA with a number of damages do not undergo repair in mitochondria $[51,70,71]$. Further studies determined that several DNA damages, which are the results of deamination, alkylation and oxidation reactions, are effectively repaired in mitochondria [72]. By now it is known that in mitochondria of the mammalians there are functioning base excision repair system (by ways SP-BER and LP-BER), repair of single strand breaks, SSBR, repairs of mismatched bases, MMR, direct repair, DR [7, 10, 34, 73]. Also there are the data on the presence of homologous and non-homologous recombination of double-strand gaps, elimination of pre mu- tagenic deoxynucleotides from deoxynucleoties pool, damaged mtDNA degradation [10].

However, it is still unknown, in which way the damages are being repaired such as cysplastine interstrand crosslinks of mtDNA, pyrimidine dimers, 8,5'-cyclo-2'-deoxypurines, adducts of DNA and malonic aldehyde, benzo[a]pyrene diol epoxide, proteins and other damages, that are the substrates of nucleotide excision repair in nucleus [54, 56, 60, 71]. Notably, the absence or low efficacy of DNA repair systems, which leads to accumulation of damages and mutations in mtDNA, raises probability of expression of mutant genes in mtDNA and insertion of mutant proteins in ETC. Above-mentioned process, for its part, can lead to an increased level of AFO and further damaging of mtDNA, and expression of mutant proteins. Thus, positive feedback is being created between the number of AFO and stability of mtDNA $[7,37]$. If the repair systems function inefficiently, it can lead to the mitochondrial dysfunction and later to the dysfunction of a whole cell.

\section{Base excision repair, BER}

Base excision repair, or BER, is historically the first repair system found in mitochondria, and by now it remains the most studied one [74]. BER mainly deals

\section{DSB-Clustered DNA Damage}

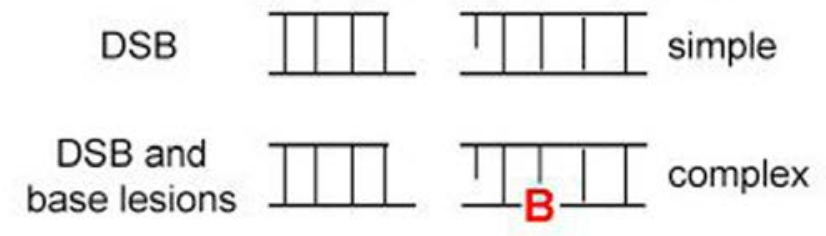

\section{Non-DSB-Clustered DNA Damage}

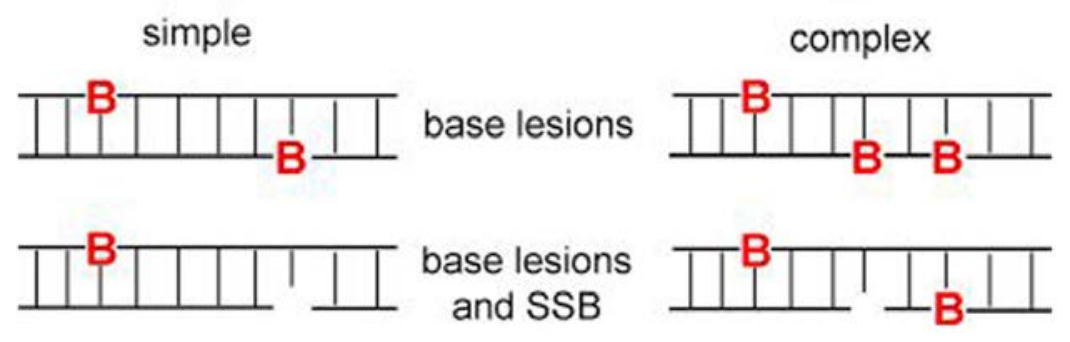

Fig. 2. Shceme of possible clustered damages [64]. Basic classification of clustered damages is based on division into damages having and nonhaving TS-gap. $B-$ damaged DNA base. 
with repair of small heterocyclic bases formed as a result of oxidation, deamination, alkylation reactions and spontaneous hydrolysis, which do not make big changes in the double-helix DNA structure. Most of the proteins participating in the mitochondrial BER system are transcriptional isoforms of genes which code nucleic proteins $[7,34,73]$. Besides, part of the nucleic repair proteins is undergoing posttranslational modification and also participates in the repair processes in mitochondria $[7,75,76]$.

The BER process in mitochondria, like the process in the nucleus, includes four basic stages: 1) detection of damaged nucleotide and the cleavage of $\mathrm{N}$-glycosidic bond by base specific DNA-glycosylases, and finishing with formation of AP site; 2) cleaving AP site by AP endonuclease with formation of single-nucleotide gap with 3'-and 5'-dRP ends; 3 ) deletion of the dRP fragment by the dRP-lyase activity of DNA polymerase with simultaneous inclusion of an additional nucleotide in the formed gap by polymerase activity; 4) ligation of single-strand gap by the DNA ligase [77]. Above-described stages characterize SP-BER, which results in deletion of damaged base and insertion of one nucleotide. LPBER repair is carried out when after the second stage of process, 5'-dRP in the gap is modified and cannot be deleted by dRP-lyase activity of polymerase. In this case DNA-polymerase includes from 6 to 9 nucleotides and provides synthesis with exclusion of the chain with a damaged 5'-end [78]. The excluded "hanging" single-stranded part of DNA is being deleted by endonucleases FEN1, EXOG, DNA2, and the gap is being ligated by DNA-ligase III. Fig. 3 represents the scheme of BER in mammalians' mitochondria.

Currently it is known that in the mitochondrial BER system the monofunctional - MYH, UDG, and bifunctional - OGG1, NEIL1, NEIL2, NEIL3 DNA glycosylases participate $[7,34,51]$. The DNA glycosylase OGG1 repair mainly oxidized purines. DNA glycosylase MYH identifies adenine residue which is incorrectly paired with 8-oxoguanine and deletes it. It is known that nuclear and mitochondrial MYH are formed as a result of alternative splicing of hu- man gene $M Y H$ having three different transcripts, each of which has 10 variants of alternative splicing. The DNA glycosylase NTH1 identifies a number of damages in pyrimidine nucleotide depending on the nucleotide located oppositely to the damage. The DNA glycosylase UDG identifies uracil, formed as a result of deamination of cytosine, and a number of oxidized forms of cytosine, including 5-hydroxy uracil. The mitochondrial form of DNA glycosylase $\mathrm{UNG}$, UNG1, is formed as a result of alternative splicing and transcription from different positions of gene $U N G$. Glycosylases NEIL1, NEIL2 and NEIL3 delete mainly formamidopyrinic derivatives of guanine, but they are able to process the oxidized bases depending on the nucleotide located oppositely to the damage $[7,80]$.

After the stage of deletion of a damaged base the stage of splitting mtDNA chain containing AP site comes ; according to the recent data, this stage is catalyzed by mitochondrial APE1, a shortened form of full-size nuclear APE1 [81]. At the next stage of mtBER, the DNA polymerase $\gamma$ deletes residue 5'dRP with formation of 5'-phosphate and inserts nucleotide into th emerged gap [82, 83]. Pol $\gamma$ is the only DNA polymerase in mitochondria, which possesses both DNA-polymerizing and dRP-lysing activities and participates in replication, repair and recombination of mtDNA.

The final stage of mtBER is ligation of singlestrand break by DNA ligase. Mitochondrial DNA ligase is a variant of the nuclear DNA ligase III and is formed via an alternative start of translation from one matrix RNA [84]. Mitochondrial ligase, unlike the nuclear one, can function without XRCC1 protein, which forms stable complex with the nuclear DNA ligase III [85].

The studies showed that during the BER process in nuclei of mammalian cells AP endonuclease cleaves more than $95 \%$ of emerging AP sites, but there is an alternative way with participation of bifunctional DNA glycosylases [86-88], this way is also typical for the mitochondrial BER system. Such bifunctional glycosylases as OGG1 and NTH1 after the cleavage of the N-glycosidic bond cut the AP site 


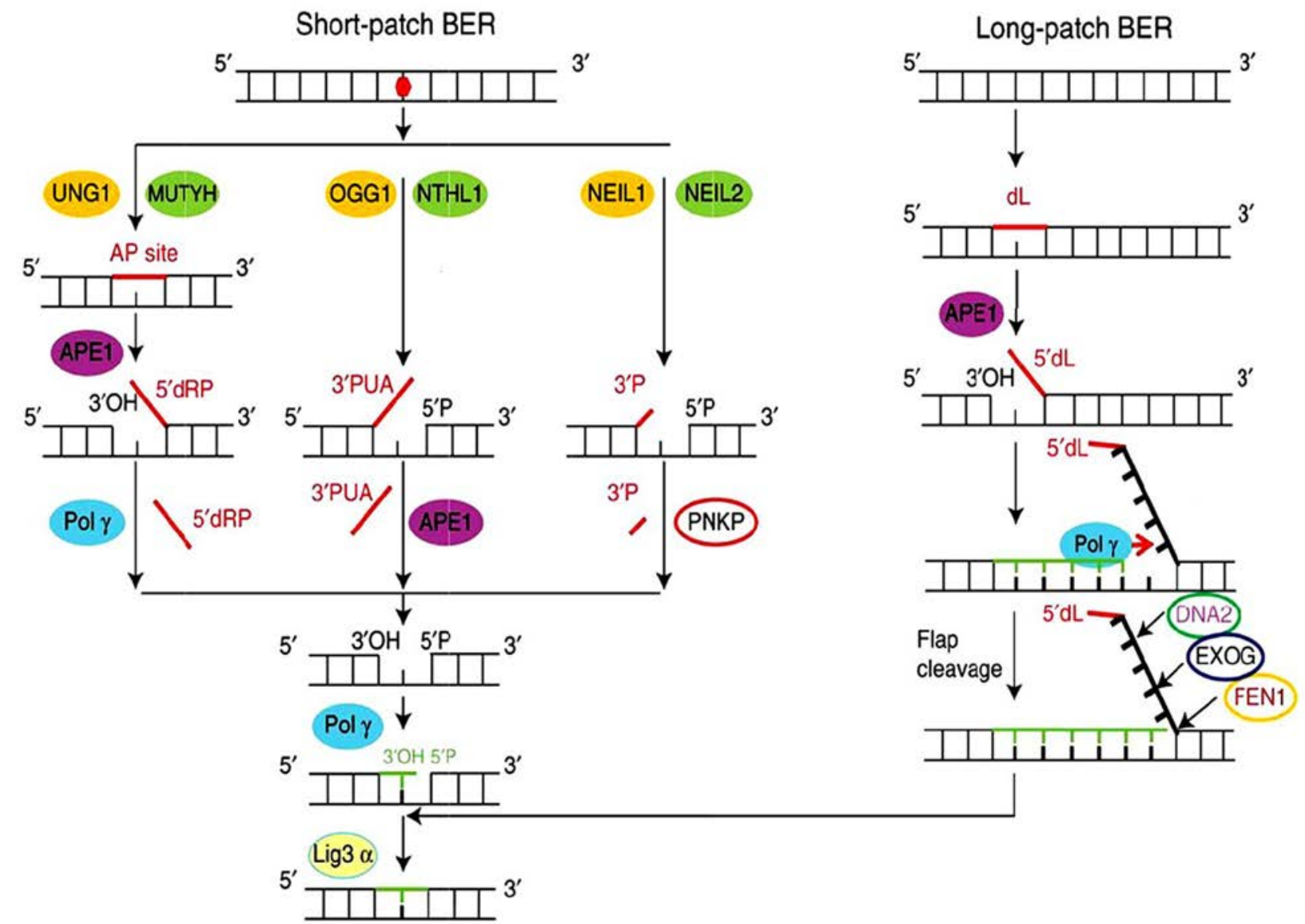

Fig. 3. Scheme of BER in mammalians' mitochondria [79]. Three different branches of SP-BER are intersecting at stage of filling the gap. SP-BER and LP-BER ways are intersecting at stage of filling the gap. Endonuclease DNA2, in addition to FEN1, is necessary for effective processing of excluded fragment of chain.

by $\beta$-elimination mechanism; as a result, a gap emerges with 3'-unsaturated phosphoaldehyde PUA and 5'-phosphate group at the ends. 3'-PUA is then removed by AP-endonuclease with formation of 3'$\mathrm{OH}$ [89]. Next insertion of nucleotide by DNA polymerase and ligation by DNA ligase occur, as described above. Such bifunctional DNA glycosylases as NEIL1 and NEIL2 possess $\beta, \delta$-eliminating activity. As a result, after cleavage of the AP site, a single-nucleotide gap with 3' and 5'- phosphate groups at its ends is formed [89]. The presence of phosphate group at 3'-end completely blocks the insertion of nucleotide by DNA polymerase, thus, 3'-end has to be processed with help of polynucleotidekinase-3'phosphatase, PNKP, which leaves 3'-OH at the gap's end [90]. At the next stages BER run analogically to those reviewed above.

Because of close proximity of the mtDNA and ETC complex, the formation of large number of modified AP sites and residues of deoxyribolacton seems feasible. Such damages can inhibit the mtDNA replication due to the formation of covalent crosslinks between DNA polymerase and the damaged residue. As it was noted above, repair of modified AP sites mostly follows the path LP-BER. In the process of studying the mitochondrial LP-BER it was revealed that the flap endonuclease activity FEN1 is duplicated by the activity of enzyme nuclease/helicase DNA2, which is well known from the nuclear process of DNA replication [10, 91, 92]. 
Currently it is believed that both FEN1 and DNA2 (or EXOG) take part in LP-BER [91, 93, 94].

\section{Single-strand break repair, SSBR}

Single-strand breaks (SSB) emerge in the cell as a result of AFO influence, and also as intermediates of the BER process stages. Thus, they can accumulate when certain BER stages are violated. Unrepairable SSB possessing 3'- or 5' -ends can stop transcription and replication and may be a cause of double-strand breaks. SSB can also be a result of incorrect functioning of topoisomerase 1, which participates in the mtDNA transcription and replication [45]. Such damages are repaired by tyrosyl-DNA-phosphodiesterase 1, TDP1 [95]. SSB possessing at 5'-end adenosine monophosphate, covalently bound to 5'-phosphate, emerge due to incorrect functioning of DNA ligase III and are repaired with participation of protein aprataxin APTX [96]. The enzymatic base of the SSBR system consists of the BER system proteins [7]. In nucleus, SSB are detected by the protein poly(ADP-ribose)polymerase 1, PARP1 [97, 98]. Numerous studies were carried out to discover PARP1 and define its functions in mitochondria, but the results obtained are contradictory [99-103].

To provide direct participation of PARP1 in the maintenance of mtDNA integrity, the PLA (proximity ligation assay) method in situ was used, which allows revealing close proximity of two proteins or their interaction. In such a way, the interactions between PARP1 and specific mitochondrial proteins OXOG and catalytic subunit pol $\gamma$ were detected [104]. Further experiments showed that the silencing of PARP1 gene with the help of siRNA or inhibition of PARP1 influences positively the stability and integrity of mtDNA [104]. In favor of a hypothesis about the negative influence of PARP1 on the mtDNA stability testifies an increase in the number (amplification of PLA signal) of interacting proteins in pairs PARP1-OXOG and PARP1- catalytic subunit pol $\gamma$, and also raise of activity of DNA repair in silencing PARP1 expression. Regarding the mitochondria functioning it was shown that in silencing $P A R P 1$ gene expression the activity of citrate syn- thase raises by $30 \%$, and the number of copies of mtDNA raises by $50 \%$ [104]. Taken together, these data indicate the improvement of mitochondria homeostasis at suppression of the PARPl gene expression [104].

\section{Repair of non-complementary pairs (mis- match repair), MMR}

MMR repairs mistakenly paired bases and small loops - insertions emerging as a result of mistakes of DNA polymerase during replication. The studies showed that in mitochondria of higher eukaryotes there are no proteins MSH1, MSH2, MSH6 and MHL1, which participate in MMR process in nucleus $[7,10]$. However, in 2003 it was shown that enzymatic activities, which allow the restoration of integrity of DNA containing non-complementary sites, are present in mitochondrial extracts [8]. It was revealed that this reaction requires polyfunctional protein YB-1 (Y-box binding protein), which is located in nucleus, cytoplasm and in mitochondria [9]. Unfortunately, the details of the process and the mechanism of DNA repair are still undefined.

\section{Homologous, HR, and non-homologous, NHEJ, double-strand break repair}

Recombination activity was found for the first time in the mitochondrial extracts of mammals in 1999; at that time the basic enzymes of this process were considered to be DNA ligase III and one of variants of $\mathrm{Ku} 80$ protein [105]. However, the presence of Ku80 in mitochondria is still unconfirmed. Intermediates of recombination processes were found in patients having deletions in mtDNA of cardiac muscle cells [11]. The recombinant form of mtDNA was discovered in patients with unusual hereditary changes in the mitochondrial genome [12]. Later the data were obtained evidencing alternative ways of non-homologous recombination, MMEJ, in mammalian mitochondria [106]. In 2010 one of key proteins-participants of homologous recombination, RAD259, was found in mitochondria: it was discovered to accumulate in this organelle under conditions of oxidative stress [107]. However, the studies did not prove di- 
rect participation of RAD59 in the homologous recombination process.

The raghavan group's studies showed that a classical way of non-homologous recombination is absent in mitochondria, while in nucleus both ways, classical and alternative NHEJ, are functioning [106, 108]. Alternative way of non-homologous recombination is the main way of double-strand breaks repair in mtDNA. Implementation of this process requires the presence of micro homology with length of 5 or more nucleotide pairs at blunt ends of sites which are recombined. In fig. 4 the scheme of recombination of break in different ways of non-homologous recombination is presented.

It remains unknown whether alternative recombination is carried out via one or a number of mechanisms using micro homology. With use of biochemical methods it was proved that formation of alternative recombination products depends on proteins MRE11, NBS1, DNA ligase III, XRCC1, CtIP, FEN1, PARP1 and does not depend on proteins $\mathrm{Ku} 70, \mathrm{Ku} 80$, DNA ligase IV participating in C-NHEJ [108]. However, a precise mechanism of A-NHEJ remains unknown. It is obvious that recombination by the way A-NHEJ is the most undesirable one, because due to this process more nucleotides are lost than in the processes HR or C-NHEJ, but since C-NHEJ is absent in mitochondria and there are no data on the mechanism and participants of HR, we can consider the A-NHEJ mechanism as the main one.

\section{Nucleotide excision repair, NER}

A hypothesis about the absence of effective NER system in mitochondria was stated in 1982 based on the results of experiments which showed that integrity of mtDNA subjected to UV-radiation does not restore [109]. Later similar data were obtained by other researchers [71]. Notably, the repair of cysplatinum adducts, which runs in nucleus by the systems of interstrand crosslinks, ISCR, and NER, nonetheless takes place in mitochondria. However it is currently considered that the recombination system is involved in effective repair of interstrand crosslinks $[74,110]$. On the other hand, the total absence of NER system responsible for wide range of DNA damages including adducts with xenobiotics is unlikely, because it should lead inevitably to problems with the mtDNA transcription and further disorders of mitochondrial functions $[51,111,112]$. An indirect evidence of the NER system presence in mito-

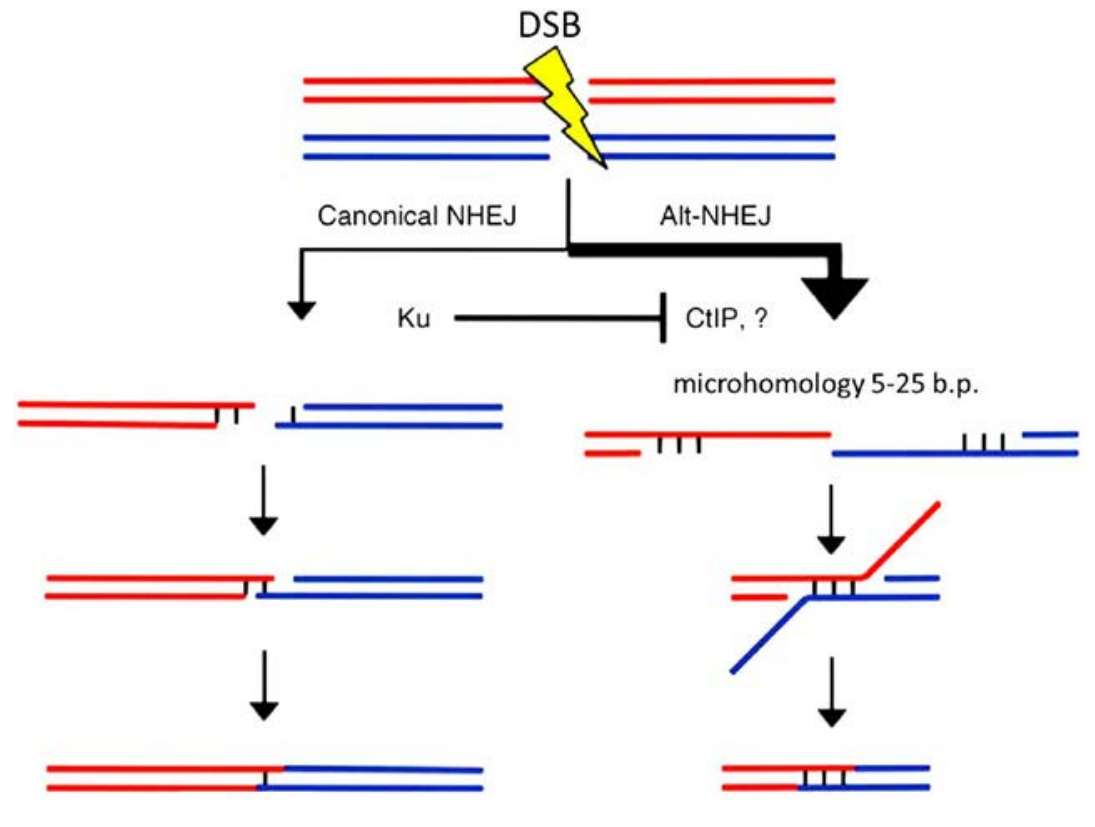

Fig. 4. Scheme of recombination of double-strand break in classic (C-NHEJ) and alternative (A-NHEJ) ways of homologous recombination. 
chondria is discovery of proteins CSA, Cockayne syndrome A complementing protein, and CSB, Cockayne syndrome B complementing protein, which are the necessary components of the TC-NER way connected to NER $[51,113,114]$. A role of proteins CSA/B remains unclear for now. It is not excluded that the mitochondrial fraction of CSB protein plays a role in the interaction of proteins of $\mathrm{mt}-$ BER system and inner membrane of organelle, with which nucleotides are connected [113, 115]. Nowadays, the absence of the NER system and related to it problems of bulky lesions repair is one of key issues in studies of the mtDNA repair.

\section{Degradation of damaged mitochondrial DNA}

A hypothesis about the existence of specialized mtDNA degradation system arose after experiments, which demonstrated the absence of effective NER system in mitochondria [70, 71]. Possibility of using the degradation system instead of the DNA integrity restoration systems was supported by the fact of existence of multiple copies of mtDNA $[24,116]$. An additional evidence in favor of existence of these systems were the results of experiments, in which the mtDNA state was studied under exogenous introduction of sequence-specific endonucleases of restriction, which cause the additional breaks in mtDNA, directly in organelles $[117,118]$. In case when the endonucleases activity was high and the number of double-strand breaks was large, the authors noticed a depletion of mtDNA in the cell. If the activity of specific endonucleases was low, the authors noticed a higher activity of the mtDNA recombination systems [119]. The resistance of mammalian mitochondria against a number of mutagens and oxidative stress was shown [118, 120].

The studies showed that damages of bases "ineffectively" lead to the mutations in mtDNA after replication, whereas in nuclear DNA most of such damages became mutations after replication. Perhaps, selective degradation of damaged mtDNA took place, and further replication was carried out with undamaged mtDNA. The mechanisms of specific degradation of damaged mtDNA remain unknown at the moment. We can presume that a launching signal for such system is related to a stop of DNA or RNA polymerases on damaged matrix DNA, AP sites and chain breaks - structures unrecognizable for DNA polymerases as the coding information $[10,121]$.

\section{Cluster damage repair}

The majority of studies on the cluster damage repair in mammalian cells were carried out on so-called "double-stranded clusters" - DNA model containing damages in both strands. A choice of such DNA damage is caused by its possible turning into the double-stranded DNA break [122]. Despite coordinated functioning of the repair systems, approximately $10 \%$ of the cluster damages induced by $\gamma$-radiation, turn into the double-stranded breaks within 30 minutes in the NHEJ-defective cells of Chinese hamster [123]. It is also possible that damaged DNA can go through replication, and the damage will remain only in one strand [124].

Due to the complexity of cluster damages and the variety of proteins participating in the repair initiation it is hard to say how exactly an individual damage is being repaired. The studies on the doublestranded cluster damages containing two uracils, two furans, two 8-oxoG and furan opposite 8-oxoG, showed that such damages are repaired mostly with help of the BER system, though the initial stages of detection of different damages such as AP sites, single-stranded breaks and oxidative base damages can differ $[67,125,126]$. Summarizing the results of a number of studies, we could outline several factors influencing the transformation of the cluster damage into the double-strand break: the expression level of protein recognizing the damage, the distance and location of damages relative to each other, efficacy of damage [63]. Fig. 5 presents an example of the cluster damage repair.

All currently known data on the cluster damages were obtained while studying the whole-cell or nuclear extracts. There are no data in literature about how such damages are repaired in mitochondria. The presence of BER system in mitochondria implies the cluster damage repair with its participation, but due 

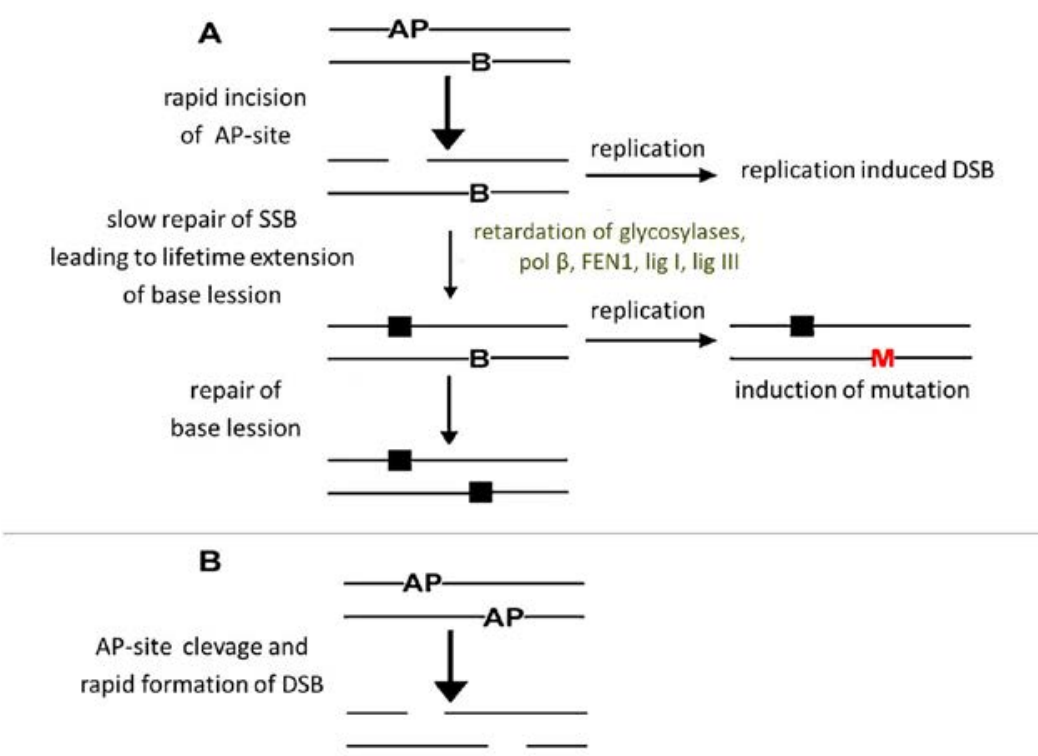

Fig. 5. Scheme of repair of cluster damage containing AP site and damaged base [64]. $A$ - after AP site cleavage[,] emerging single-stranded break inhibits repair of damaged base until ss-break is repaired, thereby limiting formation of dsbreak; if replication of DNA with ssbreak occurs, collapse of movement of the replicative fork and the formation of ds-gap are possible; if damaged base is not repaired in time and is replicated as it is, possibility of mutation will occur. $B-$ two AP sites located in both chains are often cleaved fast with formation of dsbreak, unless AP sites are located within two base pairs and are not directed 5' -3 ' relative to each other. to a complex structure of the cluster damages and a possible involvement of the proteins which are not part of the BER system, a question about the repair mechanisms remains open.

Work is performed with support of RFBR (grant 15-04-06690).

\section{REFERENCES}

1. Dyall SD, Brown MT, Johnson PJ. Ancient invasions: from endosymbionts to organelles. Science. 2004;304(5668): 253-7.

2. Gupta S. Molecular steps of death receptor and mitochondrial pathways of apoptosis. Life Sci. 2001;69(25-26): 2957-64.

3. Hsu TC, Young MR, Cmarik J, Colburn NH. Activator protein 1 (AP-1)- and nuclear factor kappaB (NF-kappaB)-dependent transcriptional events in carcinogenesis. Free Radic Biol Med. 2000;28(9):1338-48.

4. Bauer MF, Gempel K, Hofmann S, Jaksch M, Philbrook C, Gerbitz KD. Mitochondrial disorders. A diagnostic challenge in clinical chemistry. Clin Chem Lab Med. 1999; 37(9):855-76.

5. Han D, Dara L, Win S, Than TA, Yuan L, Abbasi SQ, Liu ZX, Kaplowitz $N$. Regulation of drug-induced liver injury by signal transduction pathways: critical role of mitochondria. Trends Pharmacol Sci. 2013;34(4):243-53.

6. Druzhyna NM, Wilson GL, LeDoux SP. Mitochondrial DNA repair in aging and disease. Mech Ageing Dev. 2008;129(78):383-90.
7. Muftuoglu M, Mori MP, de Souza-Pinto NC. Formation and repair of oxidative damage in the mitochondrial DNA. Mitochondrion. 2014;17:164-81.

8. Mason PA, Matheson EC, Hall AG, Lightowlers RN. Mismatch repair activity in mammalian mitochondria. Nucleic Acids Res. 2003;31(3):1052-8.

9. de Souza-Pinto NC, Mason PA, Hashiguchi K, Weissman L, Tian J, Guay D, Lebel M, Stevnsner TV, Rasmussen LJ, Bohr $V A$. Novel DNA mismatch-repair activity involving YB-1 in human mitochondria. DNA Repair (Amst). 2009;8(6):704-19.

10. Liu P, Demple B. DNA repair in mammalian mitochondria: Much more than we thought? Environ Mol Mutagen. 2010; 51(5):417-26.

11. D'Aurelio M, Gajewski CD, Lin MT, Mauck WM, Shao LZ, Lenaz G, Moraes CT, Manfredi G. Heterologous mitochondrial DNA recombination in human cells. Hum Mol Genet. 2004;13(24):3171-9.

12. Kraytsberg Y, Schwartz M, Brown TA, Ebralidse K, Kunz WS, Clayton DA, Vissing J, Khrapko K. Recombination of human mitochondrial DNA. Science. 2004;304(5673):981.

13. Bellance $N$, Lestienne $P$, Rossignol R. Mitochondria: from bioenergetics to the metabolic regulation of carcinogenesis. Front Biosci (Landmark Ed). 2009;14:4015-34.

14. Shokolenko IN, Alexeyev MF. Mitochondrial DNA: A disposable genome? Biochim Biophys Acta. 2015;1852(9):1805-9.

15. Basu S, Bremer E, Zhou C, Bogenhagen DF. MiGenes: a searchable interspecies database of mitochondrial proteins curated using gene ontology annotation. Bioinformatics. 2006;22(4):485-92.

16. Holt IJ, Reyes A. Human mitochondrial DNA replication. Cold Spring Harb Perspect Biol. 2012;4(12). pii: a012971. 
17. Holt IJ, Jacobs HT. Unique features of DNA replication in mitochondria: a functional and evolutionary perspective. Bioessays. 2014;36(11):1024-31.

18. Kukat C, Wurm CA, Spåhr H, Falkenberg M, Larsson $N G$, Jakobs $S$. Super-resolution microscopy reveals that mammalian mitochondrial nucleoids have a uniform size and frequently contain a single copy of mtDNA. Proc Natl Acad Sci U S A. 2011;108(33):13534-9.

19. Ngo HB, Kaiser JT, Chan DC. The mitochondrial transcription and packaging factor Tfam imposes a U-turn on mitochondrial DNA. Nat Struct Mol Biol. 2011;18(11):1290-6.

20. Rubio-Cosials A, Sidow JF, Jiménez-Menéndez N, Fernández-Millán P, Montoya J, Jacobs HT, Coll M, Bernadó P, Solà $M$. Human mitochondrial transcription factor A induces a U-turn structure in the light strand promoter. Nat Struct Mol Biol. 2011;18(11):1281-9.

21. Wang $Y$, Bogenhagen DF. Human mitochondrial DNA nucleoids are linked to protein folding machinery and metabolic enzymes at the mitochondrial inner membrane. J Biol Chem. 2006;281(35):25791-802.

22. Singh $B$, Li $X$, Owens $K M$, Vanniarajan A, Liang $P$, Singh KK. Human REV3 DNA Polymerase Zeta Localizes to Mitochondria and Protects the Mitochondrial Genome. PLoS One. 2015;10(10):e0140409.

23. Makarova $A V$, Burgers PM. Eukaryotic DNA polymerase $\zeta$. DNA Repair (Amst). 2015;29:47-55.

24. Figge MT, Reichert AS, Meyer-Hermann M, Osiewacz HD. Deceleration of fusion-fission cycles improves mitochondrial quality control during aging. PLoS Comput Biol. 2012;8(6):e1002576.

25. Greaves $L C$, Taylor $R W$. Mitochondrial DNA mutations in human disease. IUBMB Life. 2006;58(3):143-51.

26. Gilkerson $R W$. Mitochondrial DNA nucleoids determine mitochondrial genetics and dysfunction. Int J Biochem Cell Biol. 2009;41(10):1899-906.

27. Torroni A, Huoponen K, Francalacci P, Petrozzi M, Morelli L, Scozzari R, Obinu D, Savontaus ML, Wallace DC. Classification of European mtDNAs from an analysis of three European populations. Genetics. 1996;144(4):1835-50.

28. Chinnery PF, Hudson G. Mitochondrial genetics. Br Med Bull. 2013;106:135-59.

29. Zapico SC, Ubelaker DH. mtDNA Mutations and Their Role in Aging, Diseases and Forensic Sciences. Aging Dis. 2013;4(6):364-80.

30. Indo HP, Yen HC, Nakanishi I, Matsumoto K, Tamura M, Nagano Y, Matsui H, Gusev O, Cornette R, Okuda T, Minamiyama Y, Ichikawa H, Suenaga S, Oki M, Sato T, Ozawa T, Clair DK, Majima HJ. A mitochondrial superoxide theory for oxidative stress diseases and aging. J Clin Biochem Nutr. 2015;56(1):1-7.

31. Ziegler $D V$, Wiley $C D$, Velarde $M C$. Mitochondrial effectors of cellular senescence: beyond the free radical theory of aging. Aging Cell. 2015;14(1):1-7.
32. Dai DF, Chiao YA, Marcinek DJ, Szeto HH, Rabinovitch PS. Mitochondrial oxidative stress in aging and healthspan. Longev Healthspan. 2014;3:6.

33. Wei YH, Lee HC. Oxidative stress, mitochondrial DNA mutation, and impairment of antioxidant enzymes in aging. Exp Biol Med (Maywood). 2002;227(9):671-82.

34. Boesch P, Weber-Lotfi F, Ibrahim N, Tarasenko V, Cosset A, Paulus $F$, Lightowlers $R N$, Dietrich A. DNA repair in organelles: Pathways, organization, regulation, relevance in disease and aging. Biochim Biophys Acta. 2011;1813(1):186200.

35. Kowaltowski AJ, de Souza-Pinto NC, Castilho RF, Vercesi $A E$. Mitochondria and reactive oxygen species. Free Radic Biol Med. 2009;47(4):333-43.

36. Zhong H, Yin H. Role of lipid peroxidation derived 4-hydroxynonenal (4-HNE) in cancer: focusing on mitochondria. Redox Biol. 2015;4:193-9.

37. Gaziev AI. [Pathways for maintenance of mitochondrial DNA integrity and mitochondrial functions in cells exposed to ionizing radiation]. Radiats Biol Radioecol. 2013;53(2): 117-36.

38. Daiber A. Redox signaling (cross-talk) from and to mitochondria involves mitochondrial pores and reactive oxygen species. Biochim Biophys Acta. 2010;1797(6-7):897-906.

39. Csordás G, Hajnóczky G. SR/ER-mitochondrial local communication: calcium and ROS. Biochim Biophys Acta. 2009;1787(11):1352-62.

40. Nazarewicz RR, Dikalov SI. Mitochondrial ROS in the prohypertensive immune response. Am J Physiol Regul Integr Comp Physiol. 2013;305(2):R98-100.

41. Bigarella $C L$, Liang $R$, Ghaffari $S$. Stem cells and the impact of ROS signaling. Development. 2014;141(22):4206-18.

42. Labunskyy VM, Gladyshev VN. Role of reactive oxygen species-mediated signaling in aging. Antioxid Redox Signal. 2013;19(12):1362-72.

43. Wagner $S$, Rokita AG, Anderson ME, Maier LS. Redox regulation of sodium and calcium handling. Antioxid Redox Signal. 2013;18(9):1063-77.

44. Nakamura J, Swenberg JA. Endogenous apurinic/apyrimidinic sites in genomic DNA of mammalian tissues. Cancer Res. 1999;59(11):2522-6.

45. Kasiviswanathan R, Collins TR, Copeland WC. The interface of transcription and DNA replication in the mitochondria. Biochim Biophys Acta. 2012;1819(9-10):970-8.

46. Kasiviswanathan R, Gustafson MA, Copeland WC, Meyer JN. Human mitochondrial DNA polymerase $\gamma$ exhibits potential for bypass and mutagenesis at UV-induced cyclobutane thymine dimers. J Biol Chem. 2012;287(12):9222-9.

47. Nakanishi N, Fukuoh A, Kang D, Iwai S, Kuraoka I. Effects of DNA lesions on the transcription reaction of mitochondrial RNA polymerase: implications for bypass RNA synthesis on oxidative DNA lesions. Mutagenesis. 2013;28(1): 117-23. 
48. Adelman R, Saul RL, Ames BN. Oxidative damage to DNA: relation to species metabolic rate and life span. Proc Natl Acad Sci U S A. 1988;85(8):2706-8.

49. Bjelland $S$, Eide L, Time RW, Stote R, Eftedal I, Volden G, Seeberg E. Oxidation of thymine to 5-formyluracil in DNA: mechanisms of formation, structural implications, and base excision by human cell free extracts. Biochemistry. 1995; 34(45):14758-64.

50. Kobashigawa S, Kashino G, Suzuki K, Yamashita S, Mori H. Ionizing radiation-induced cell death is partly caused by increase of mitochondrial reactive oxygen species in normal human fibroblast cells. Radiat Res. 2015;183(4):455-64.

51. Cline $S D$. Mitochondrial DNA damage and its consequences for mitochondrial gene expression. Biochim Biophys Acta. 2012;1819(9-10):979-91.

52. Swenberg JA, Lu K, Moeller BC, Gao L, Upton PB, Nakamura J, Starr TB. Endogenous versus exogenous DNA adducts: their role in carcinogenesis, epidemiology, and risk assessment. Toxicol Sci. 2011;120 Suppl 1:S130-45.

53. Matsuda T, Yabushita H, Kanaly RA, Shibutani S, Yokoyama $A$. Increased DNA damage in ALDH2-deficient alcoholics. Chem Res Toxicol. 2006;19(10):1374-8.

54. Yu HS, Oyama T, Isse T, Kitagawa K, Pham TT, Tanaka M, Kawamoto T. Formation of acetaldehyde-derived DNA adducts due to alcohol exposure. Chem Biol Interact. 2010; 188(3):367-75.

55. Backer JM, Weinstein IB. Interaction of benzo(a)pyrene and its dihydrodiol-epoxide derivative with nuclear and mitochondrial DNA in C3H10T $1 / 2$ cell cultures. Cancer Res. 1982;42(7):2764-9.

56. Khan $Q A$, Kohlhagen $G$, Marshall R, Austin CA, Kalena GP, Kroth H, Sayer JM, Jerina DM, Pommier Y. Position-specific trapping of topoisomerase II by benzo[a]pyrene diol epoxide adducts: implications for interactions with intercalating anticancer agents. Proc Natl Acad Sci U S A. 2003;100(21):12498-503.

57. Schlezinger JJ, White RD, Stegeman JJ. Oxidative inactivation of cytochrome P-450 1A (CYP1A) stimulated by 3,3',4,4'-tetrachlorobiphenyl: production of reactive oxygen by vertebrate CYP1As. Mol Pharmacol. 1999;56(3):588-97.

58. Biswas $G$, Srinivasan $S$, Anandatheerthavarada $H K$, Avadhani $N G$. Dioxin-mediated tumor progression through activation of mitochondria-to-nucleus stress signaling. Proc Natl Acad Sci U S A. 2008;105(1):186-91.

59. Dedon PC, Goldberg $I H$. Free-radical mechanisms involved in the formation of sequence-dependent bistranded DNA lesions by the antitumor antibiotics bleomycin, neocarzinostatin, and calicheamicin. Chem Res Toxicol. 1992;5(3):311-32.

60. Ang WH, Myint M, Lippard SJ. Transcription inhibition by platinum-DNA cross-links in live mammalian cells. $J$ Am Chem Soc. 2010;132(21):7429-35.

61. Todd RC, Lippard SJ. Inhibition of transcription by platinum antitumor compounds. Metallomics. 2009;1(4):280-91.
62. Georgakilas $A G, O^{\prime} N e i l l P$, Stewart $R D$. Induction and repair of clustered DNA lesions: what do we know so far? Radiat Res. 2013;180(1):100-9.

63. Sage E, Harrison L. Clustered DNA lesion repair in eukaryotes: relevance to mutagenesis and cell survival. Mutat Res. 2011;711(1-2):123-33.

64. Eccles LJ, O'Neill P, Lomax ME. Delayed repair of radiation induced clustered DNA damage: friend or foe? Mutat Res. 2011;711(1-2):134-41.

65. Budworth H, Dianov GL. Mode of inhibition of short-patch base excision repair by thymine glycol within clustered DNA lesions. J Biol Chem. 2003;278(11):9378-81.

66. Budworth H, Dianova II, Podust VN, Dianov GL. Repair of clustered DNA lesions. Sequence-specific inhibition of long-patch base excision repair be 8-oxoguanine. J Biol Chem. 2002;277(24):21300-5.

67. Malyarchuk S, Castore R, Harrison L. DNA repair of clustered lesions in mammalian cells: involvement of non-homologous end-joining. Nucleic Acids Res. 2008;36(15):4872-82.

68. Shikazono N, Noguchi M, Fujii K, Urushibara A, Yokoya A. The yield, processing, and biological consequences of clustered DNA damage induced by ionizing radiation. $J$ Radiat Res. 2009;50(1):27-36.

69. Khanna KK, Jackson SP. DNA double-strand breaks: signaling, repair and the cancer connection. Nat Genet. 2001; 27(3):247-54.

70. Clayton DA, Doda JN, Friedberg EC. The absence of a pyrimidine dimer repair mechanism in mammalian mitochondria. Proc Natl Acad Sci U S A. 1974;71(7):2777-81.

71. Pascucci B, Versteegh A, van Hoffen A, van Zeeland AA, Mullenders $L H$, Dogliotti E. DNA repair of UV photoproducts and mutagenesis in human mitochondrial DNA. J Mol Biol. 1997;273(2):417-27.

72. Croteau DL, Stierum RH, Bohr VA. Mitochondrial DNA repair pathways. Mutat Res. 1999;434(3):137-48.

73. Gredilla R, Bohr VA, Stevnsner T. Mitochondrial DNA repair and association with aging--an update. Exp Gerontol. 2010;45(7-8):478-88.

74. LeDoux SP, Wilson GL, Beecham EJ, Stevnsner T, Wassermann K, Bohr VA. Repair of mitochondrial DNA after various types of DNA damage in Chinese hamster ovary cells. Carcinogenesis. 1992;13(11):1967-73.

75. Chattopadhyay R, Wiederhold L, Szczesny B, Boldogh I, Hazra TK, Izumi T, Mitra S. Identification and characterization of mitochondrial abasic (AP)-endonuclease in mammalian cells. Nucleic Acids Res. 2006;34(7):2067-76.

76. Nakabерри Y. Regulation of intracellular localization of human MTH1, OGG1, and MYH proteins for repair of oxidative DNA damage. Prog Nucleic Acid Res Mol Biol. 2001;68:75-94.

77. Gredilla $R$. DNA damage and base excision repair in mitochondria and their role in aging. J Aging Res. 2010;2011:257093.

78. Szczesny B, Tann AW, Longley MJ, Copeland WC, Mitra S. Long patch base excision repair in mammalian mitochondrial genomes. J Biol Chem. 2008;283(39):26349-56. 
79. Alexeyev M, Shokolenko I, Wilson G, LeDoux $S$. The maintenance of mitochondrial DNA integrity--critical analysis and update. Cold Spring Harb Perspect Biol. 2013;5(5):a012641.

80. de Souza-Pinto NC, Wilson DM 3rd, Stevnsner TV, Bohr VA. Mitochondrial DNA, base excision repair and neurodegeneration. DNA Repair (Amst). 2008;7(7):1098-109.

81. Mitra S, Izumi T, Boldogh I, Bhakat KK, Chattopadhyay R, Szczesny B. Intracellular trafficking and regulation of mammalian AP-endonuclease 1 (APE1), an essential DNA repair protein. DNA Repair (Amst). 2007;6(4):461-9.

82. Copeland $W C$, Longley $M J$. DNA polymerase gamma in mitochondrial DNA replication and repair. ScientificWorldJournal. 2003;3:34-44.

83. Bailey $C M$, Anderson $K S$. A mechanistic view of human mitochondrial DNA polymerase gamma: providing insight into drug toxicity and mitochondrial disease. Biochim Biophys Acta. 2010;1804(5):1213-22.

84. Lakshmipathy $U$, Campbell $C$. The human DNA ligase III gene encodes nuclear and mitochondrial proteins. Mol Cell Biol. 1999;19(5):3869-76.

85. Lakshmipathy U, Campbell C. Mitochondrial DNA ligase III function is independent of Xrcc1. Nucleic Acids Res. 2000;28(20):3880-6.

86. Wilson DM 3rd, Barsky D. The major human abasic endonuclease: formation, consequences and repair of abasic lesions in DNA. Mutat Res. 2001;485(4):283-307.

87. Demple B, Harrison L. Repair of oxidative damage to DNA: enzymology and biology. Annu Rev Biochem. 1994;63:915-48.

88. Khodyreva $S$, Lavrik $O$. New players in recognition of intact and cleaved AP sites: implication in DNA repair in mammalian cells. In: "Selected topics in DNA Repair", InTech. 2011:305-30.

89. Drohat AC, Maiti A. Mechanisms for enzymatic cleavage of the N-glycosidic bond in DNA. Org Biomol Chem. 2014; 12(42):8367-78.

90. Akbari M, Morevati M, Croteau D, Bohr VA. The role of DNA base excision repair in brain homeostasis and disease. DNA Repair (Amst). 2015;32:172-9.

91. Duxin JP, Dao B, Martinsson P, Rajala N, Guittat L, Campbell JL, Spelbrink JN, Stewart SA. Human Dna2 is a nuclear and mitochondrial DNA maintenance protein. Mol Cell Biol. 2009;29(15):4274-82.

92. Zheng L, Zhou M, Guo Z, Lu H, Qian L, Dai H, Qiu J, Yakubovskaya E, Bogenhagen DF, Demple B, Shen B. Human DNA2 is a mitochondrial nuclease/helicase for efficient processing of DNA replication and repair intermediates. Mol Cell. 2008;32(3):325-36.

93. Kalifa L, Beutner G, Phadnis N, Sheu SS, Sia EA. Evidence for a role of FEN1 in maintaining mitochondrial DNA integrity. DNA Repair (Amst). 2009;8(10):1242-9.

94. Tann AW, Boldogh I, Meiss G, Qian W, Van Houten B, Mitra $S$, Szczesny $B$. Apoptosis induced by persistent singlestrand breaks in mitochondrial genome: critical role of
EXOG (5'-EXO/endonuclease) in their repair. J Biol Chem. 2011;286(37):31975-83.

95. Hudson JJ, Chiang SC, Wells OS, Rookyard C, El-Khamisy $S F$. SUMO modification of the neuroprotective protein TDP1 facilitates chromosomal single-strand break repair. Nat Commun. 2012;3:733.

96. Rass U, Ahel I, West SC. Actions of aprataxin in multiple DNA repair pathways. J Biol Chem. 2007;282(13):9469-74.

97. Pachkowski BF, Tano K, Afonin V, Elder RH, Takeda S, Watanabe $M$, Swenberg JA, Nakamura J. Cells deficient in PARP-1 show an accelerated accumulation of DNA single strand breaks, but not AP sites, over the PARP-1-proficient cells exposed to MMS. Mutat Res. 2009;671(1-2):93-9.

98. Ström CE, Johansson F, Uhlén M, Szigyarto CA, Erixon K, Helleday T. Poly (ADP-ribose) polymerase (PARP) is not involved in base excision repair but PARP inhibition traps a single-strand intermediate. Nucleic Acids Res. 2011;39(8): 3166-75.

99. Harris JL, Jakob B, Taucher-Scholz G, Dianov GL, Becherel OJ, Lavin MF. Aprataxin, poly-ADP ribose polymerase 1 (PARP-1) and apurinic endonuclease 1 (APE1) function together to protect the genome against oxidative damage. Hum Mol Genet. 2009;18(21):4102-17.

100. Rossi MN, Carbone M, Mostocotto C, Mancone C, Tripodi $M$, Maione R, Amati P. Mitochondrial localization of PARP-1 requires interaction with mitofilin and is involved in the maintenance of mitochondrial DNA integrity. $J$ Biol Chem. 2009;284(46):31616-24.

101. Scovassi AI. Mitochondrial poly(ADP-ribosylation): from old data to new perspectives. FASEB J. 2004;18(13):1487-8.

102. Lapucci A, Pittelli M, Rapizzi E, Felici R, Moroni F, Chiarugi $A$. Poly(ADP-ribose) polymerase-1 is a nuclear epigenetic regulator of mitochondrial DNA repair and transcription. Mol Pharmacol. 2011;79(6):932-40.

103. Bürkle A, Virág L. Poly(ADP-ribose): PARadigms and PARadoxes. Mol Aspects Med. 2013;34(6):1046-65.

104. Szczesny B, Brunyanszki A, Olah G, Mitra S, Szabo C. Opposing roles of mitochondrial and nuclear PARP1 in the regulation of mitochondrial and nuclear DNA integrity: implications for the regulation of mitochondrial function. $\mathrm{Nu}$ cleic Acids Res. 2014;42(21):13161-73.

105. Coffey G, Lakshmipathy U, Campbell C. Mammalian mitochondrial extracts possess DNA end-binding activity. $\mathrm{Nu}$ cleic Acids Res. 1999;27(16):3348-54.

106. Tadi SK, Sebastian R, Dahal S, Babu RK, Choudhary B, Raghavan SC. Microhomology-mediated end joining is the principal mediator of double-strand break repair during mitochondrial DNA lesions. Mol Biol Cell. 2016;27(2):223-35.

107. Sage JM, Gildemeister OS, Knight KL. Discovery of a novel function for human Rad51: maintenance of the mitochondrial genome. J Biol Chem. 2010;285(25):18984-90.

108. Sharma S, Javadekar SM, Pandey M, Srivastava $M, K u$ mari $R$, Raghavan SC. Homology and enzymatic require- 
ments of microhomology-dependent alternative end joining. Cell Death Dis. 2015;6:e1697.

109. Clayton DA, Doda JN, Friedberg EC. The absence of a pyrimidine dimer repair mechanism in mammalian mitochondria. Proc Natl Acad Sci U S A. 1974;71(7):2777-81.

110. Olivero OA, Chang PK, Lopez-Larraza DM, Semino-Mora $M C$, Poirier $M C$. Preferential formation and decreased removal of cisplatin-DNA adducts in Chinese hamster ovary cell mitochondrial DNA as compared to nuclear DNA. Mutat Res. 1997;391(1-2):79-86.

111. Brooks PJ, Wise DS, Berry DA, Kosmoski JV, Smerdon MJ, Somers RL, Mackie H, Spoonde AY, Ackerman EJ, Coleman $K$, Tarone RE, Robbins $J H$. The oxidative DNA lesion $8,5^{\prime}$-(S)-cyclo-2'-deoxyadenosine is repaired by the nucleotide excision repair pathway and blocks gene expression in mammalian cells. J Biol Chem. 2000;275(29):22355-62.

112. Marietta C, Gulam H, Brooks PJ. A single 8,5'-cyclo-2'deoxyadenosine lesion in a TATA box prevents binding of the TATA binding protein and strongly reduces transcription in vivo. DNA Repair (Amst). 2002;1(11):967-75.

113. Aamann MD, Sorensen MM, Hvitby C, Berquist BR, Muftuoglu M, Tian J, de Souza-Pinto NC, Scheibye-Knudsen M, Wilson DM 3rd, Stevnsner T, Bohr VA. Cockayne syndrome group B protein promotes mitochondrial DNA stability by supporting the DNA repair association with the mitochondrial membrane. FASEB J. 2010;24(7):2334-46.

114. Kamenisch Y, Fousteri M, Knoch J, von Thaler AK, Fehrenbacher B, Kato H, Becker T, Dollé ME, Kuiper R, Majora $M$, Schaller $M$, van der Horst GT, van Steeg $H$, Röcken M, Rapaport D, Krutmann J, Mullenders LH, Berneburg $M$. Proteins of nucleotide and base excision repair pathways interact in mitochondria to protect from loss of subcutaneous fat, a hallmark of aging. $J \operatorname{Exp}$ Med. 2010;207(2):379-90.

115. Scheibye-Knudsen M, Ramamoorthy M, Sykora P, Maynard S, Lin PC, Minor RK, Wilson DM 3rd, Cooper M, Spencer $R$, de Cabo R, Croteau DL, Bohr VA. Cockayne syndrome group $\mathrm{B}$ protein prevents the accumulation of damaged mitochondria by promoting mitochondrial autophagy. J Exp Med. 2012;209(4):855-69.

116. Rooney JP, Ryde IT, Sanders LH, Howlett EH, Colton MD, Germ KE, Mayer GD, Greenamyre JT, Meyer JN. PCR based determination of mitochondrial DNA copy number in multiple species. Methods Mol Biol. 2015;1241:23-38.

117. Alexeyev MF, Venediktova N, Pastukh V, Shokolenko I, Bonilla $G$, Wilson GL. Selective elimination of mutant mitochondrial genomes as therapeutic strategy for the treatment of NARP and MILS syndromes. Gene Ther. 2008;15(7):516-23.

118. Shokolenko IN, Wilson GL, Alexeyev MF. Persistent damage induces mitochondrial DNA degradation. DNA Repair (Amst). 2013;12(7):488-99.

119. Bacman SR, Williams SL, Moraes CT. Intra- and inter-molecular recombination of mitochondrial DNA after in vivo induction of multiple double-strand breaks. Nucleic Acids Res. 2009;37(13):4218-26.

120. Mita S, Monnat RJ Jr, Loeb LA. Resistance of HeLa cell mitochondrial DNA to mutagenesis by chemical carcinogens. Cancer Res. 1988;48(16):4578-83.

121. Ikeda S, Ozaki K. Action of mitochondrial endonuclease G on DNA damaged by L-ascorbic acid, peplomycin, and cisdiamminedichloroplatinum (II). Biochem Biophys Res Commun. 1997;235(2):291-4.

122. Greinert R, Volkmer B, Henning S, Breitbart EW, Greulich KO, Cardoso MC, Rapp A. UVA-induced DNA doublestrand breaks result from the repair of clustered oxidative DNA damages. Nucleic Acids Res. 2012;40(20):10263-73.

123. Gulston M, de Lara C, Jenner T, Davis E, O’Neill P. Processing of clustered DNA damage generates additional double-strand breaks in mammalian cells post-irradiation. $\mathrm{Nu}$ cleic Acids Res. 2004;32(4):1602-9.

124. Georgakilas AG, Bennett PV, Wilson DM 3rd, Sutherland $B M$. Processing of bistranded abasic DNA clusters in gamma-irradiated human hematopoietic cells. Nucleic Acids Res. 2004;32(18):5609-20.

125. Malyarchuk $S$, Harrison L. DNA repair of clustered uracils in HeLa cells. J Mol Biol. 2005;345(4):731-43.

126. Malyarchuk S, Castore R, Harrison L. Apex1 can cleave complex clustered DNA lesions in cells. DNA Repair (Amst). 2009;8(12):1343-54.

\section{Механізми репарації ДНК у мітохондріях}

\section{А. Ш. Сингатуліна, П. Є. Пестряков}

Роль мітохондрій у метаболізмі та функціонуванні клітини важко переоцінити. Мітохондрії виконують безліч функцій, головною з яких є напрацювання АТР, енергетичної "валюти" клітини. Мітохондрії мають невелику кільцеву ДНК, що кодує 13 білків. Мітохондріальна ДНК, мтДНК, також як і ядерна, знаходиться під різноманітними діями з боку навколишнього середовища і ендогенних факторів. Раніше вважалося, що системи репарації ДНК в мітохондріях відсутні, пошкоджені молекули мтДНК деградують, а реплікація і транскрипція мтДНК відбуваються 3 непошкоджених молекул, чому сприяє многокопійность мтДНК. Першим механізмом репарації, виявленим в мітохондріях, є система ексцизійної репарації основ, BER. Пізніше було знайдено систему репарації помилково спарених основ, MMR. $Є$ дані про наявність системи репарації однониткових розривів, SSBR, гомологичной і негомологичной рекомбінації дволанцюгових розривів, елімінації премутагенних дезоксинуклеотидов 3 пулу дезоксинуклеотидов, деградації пошкодженої мтДНК, але механізми роботи цих систем ще не відомі або мало вивчені. Функціонування мітохондрій безпосередньо залежить від цілісності мтДНК, а отже, від коректної роботи систем ії репарації. Пошук нових учасників репарації мтДНК становить значний інтерес і $є$ предметом активних досліджень. У цьому 
огляді представлені дані про пошкодження мтДНК і механізмах їхньої репарації.

К л юч о в і с сл о в а: Мітохондріальна ДНК, системи репарації мтДНК, пошкодження мтДНК

\section{Механизмы репарации ДНК в митохондриях}

А.Ш. Сингатулина, П. Е. Пестряков

Роль митохондрий в метаболизме и функционировании клетки трудно переоценить. Митохондрии выполняют множество функций, главной из которых является наработка АТР, энергетической “валюты” клетки. Митохондрии имеют небольшую кольцевую ДНК, кодирующую 13 белков. Митохондриальная ДНК, мтДНК, также как и ядерная, подвержена разнообразным воздействиям со стороны окружающей среды и эндогенных факторов. Ранее считалось, что системы репарации ДНК в митохондриях отсутствуют, поврежденные молекулы мтДНК деградируют, а репликация и транскрипция мтДНК происходят с неповрежденных молекул, чему способствует многокопий- ность мтДНК. Первым механизмом репарации, обнаруженным в митохондриях, является система эксцизионной репарации оснований, BER. Позднее была найдена система репарации ошибочно спаренных оснований, MMR. Есть данные о наличии системы репарации однонитевых разрывов, SSBR, гомологичной и негомологичной рекомбинации двунитевых разрывов, элиминации премутагенных дезоксинуклеотидов из пула дезоксинуклеотидов, деградации поврежденной мтДНК, но механизмы работы этих систем еще не известны или мало изучены. Функционирование митохондрий напрямую зависит от целостности мтДНК, а следовательно, от корректной работы систем ее репарации. Поиск новых участников репарации мтДНК представляет значительный интерес и является предметом активных исследований. В настоящем обзоре представлены данные о повреждениях мтДНК и механизмах их репарации.

Кл юч е в ы е с л о в а: Митохондриальная ДНК, системы репарации мтДНК, повреждения мтДНК

Received 28.05.2016 